\title{
KARYA SASTRA: \\ MIMESIS, REALITAS ATAU MITOS?
}

\begin{abstract}
Akhmad Muzakki
Ketua Pusat Kajian Bahasa dan Budaya, Fakultas Humaniora dan Budaya UIN Malang. Jalan Gajayana No. 50 Telepon (0341) 570872, Faksimile (0341) 570872 Malang 65144.
\end{abstract}

\begin{abstract}
Literature is represents falsehood, said Rahdar, but it is used as a unique procedure to reveal the truth. The imagination world ia as a contact or touch between idea and language that create literary works in certain case and it becomes the autonomous area which are not necessary to be related to the reality. Although it is imaginative, it must not be irrational because the imaginative thing is also possible to happen in real life. As a work of imagination, literary work is not able to place itself as a central of legal social problems. It is caused by the fact that literary work is an imaginative work which contraries to reality so the harmony between mimesis and author's creativity to create the new thing has great role in creating the quallified literature.
\end{abstract}

\section{Key words}

Reality, Myth, Literature, Imagination

\section{Pendahuluan}

Madzhab formalis mengatakan, sastra bukanlah suatu kepercayaan, ilmu jiwa, atau ilmu sosial. Akan tetapi ia merupakan pemakaian bahasa yang mempunyai peraturan khusus, baik dari segi struktur maupun lainnya. Karya sastra bukanlah alat untuk menyampaikan ide-ide, refleksi kenyataan yang terdapat dalam masyarakat, atau jelmaan dari nilai-nilai kebenaran yang sukar untuk 
dipahami. Tetapi karya sastra adalah kenyataan itu sendiri, dan keliru jika melihatnya sebagai ekspresi penulisnya (Atmazaki, 1990: 17).

Madzhab ini lebih mementingkan penerapan ilmu bahasa dalam pengkajian kesusastraan, karena kajian mereka lebih terfokus kepada bentuk yang dipengaruhi linguistik struktural dan melupakan isi karena isi menjadi pendorong terhadap bentuk, atau bentuk adalah isi (pesan) itu sendiri. Karena itu, mereka melihat karya sastra terdiri atas unsurunsur atau fungsi-fungsi yang selalu berubah dan saling berhubungan dalam suatu sistem tekstual, misalnya bunyi, irama, sajak, dan lain-lain. Dengan demikian, menciptakan keganjilan bagi kaum formalis merupakan inti dari kesusastraan.

Berbeda dengan teori strukturalisme genetik yang digagas Lucien Goldmann. Teori ini mengatakan, karya sastra merupakan sebuah struktur. Akan tetapi, struktur itu bukanlah sesuatu yang statis, melainkan merupakan produk dari proses sejarah yang terus berlangsung, proses strukturasi dan destrukturasi yang hidup dan dihayati oleh masyarakat asal karya sastra yang bersangkutan. Untuk menopang teorinya, Goldmann membangun seperangkat kategori yang saling bertalian satu sama lain sehingga membentuk apa yang disebutnya sebagai strukturalisme genetik. Kategori-kategori itu adalah fakta kemanusiaan, subyek kolektif, strukturasi, pandangan dunia, pemahaman dan penjelasan (Faruk, 1999:12).

Strukturalisme genetik (genetik artinya asal-usul karya sastra) merupakan sebuah pendekatan dalam penelitian sastra yang lahir sebagai reaksi dari pendekatan strukturalisme murni (formalis) yang anti-historis dan kausal. Atau, pendekatan yang hanya memusatkan perhatiannya pada otonomi sastra sebagai karya fiksi. Artinya, menyerahkan pemberian makna karya sastra tersebut terhadap eksistensi karya sastra itu sendiri tanpa mengaitkan unsur yang ada di luar struktur signifikansinya (Iswanto, 2001:61).

Dalam sosiologi sastra, karya sastra dipandang sebagai dokumen sosial yang di dalamnya menggambarkan refleksi situasi pada masa sastra tersebut diciptakan. Atau, karya sastra merupakan manifestasi 
dari kondisi sosial budaya dan peristiwa sejarah. Seperti yang pernah dilakukan Wellek dan Werren, mereka mencoba merumuskan hubungan antara sastra dan masyarakat yang dapat diteliti dengan cara; (a) faktor-faktor di luar teks, dan (b) hubungan antara teks sastra dan masyarakat (Saraswati, 2003:10).

Kedua paham di atas sesungguhnya bermuara dari persoalan memahami hakekat karya sastra. Ada yang mengatakan bahwa karya sastra sebagai karya kreatif, imajinatif, otonom, mimesis, dan sebagainya. Terlepas dari perdebatan di atas para sastrawan sepakat menyatakan, bahwa salah satu sarana yang dapat mempertemukan ide (gagasan, pikiran) dengan bahasa (aktivitas) sebagai media adalah imajinasi. Imajinasi adalah daya bayang, daya fantasi, tetapi bukan lamunan. Ia tetap berpangkal dari kenyataan-kenyataan dan pengalaman-pengalaman. Imajinasi tidaklah sama dengan realitas yang sesungguhnya (realitas obyektif). Ia bersifat intuitif yang mengutamakan faktor rasa (Dahana, 2001:25).

Hidup memang digerakkan oleh imajinasi, dibentuk oleh imajinasi, bahkan dirayakan dengan imajinasi. Melalui imajinasi manusia memahami dan membentuk dirinya, sesamanya, dan seluruh kehidupan ini. Tapi juga melalui imajinasi manusia menghancurkan diri, membunuh manusia lainnya, dan merusak bumi. Melalui imajinasi manusia mampu melihat yang tak terlihat, dan kehidupan menemukan kiblat. Karena imajinasi, manusia marah, menangis, tertawa, dan bahagia. Dunia manusia rupanya memang bukan dunia natural. Dunia manusia adalah dunia kultural: dunia imaji, dunia citraan, dunia yang diimajinasikan (Tedjoworo, 2001:9).

\section{Hakekat Sastra}

Secara intuitif, memang sangat mudah mengethui apa yang disebut sastra. Namun deskripsi dari pengertian yang ada pada pikiran kita itulah yang masih sulit dirumuskan dalam bentuk kalimat yang tepat. Jika kita mencoba merumuskan definisi sastra berdasarkan intuisi tersebut biasanya banyak gejala yang luput dari kalimat yang kita 
susun. Sebagai contoh, merumuskan kata sastra saja masih banyak perbedaan persepsi. Sastra, misalnya dalam bahasa Sansekerta barasal dari kata sas yang berarti mengarahkan, memberi petunjuk, atau instruksi, sedang tra berarti alat, atau sarana. Sedangkan sastra dalam bahasa melayu, banyak diartikan sebagai tulisan. Pengertian ini kemudian ditambah dengan kata su yang berarti indah, atau baik, sehingga susastra bermakna tulisan yang indah (Teeuw, 2003:19-23).

Dalam kamus bahasa Indonesia (1988;786), sastra berarti tulisan, huruf, bacaan, dan karangan. Sastra juga berarti bahasa (kata-kata, gaya bahasa) yang dipakai dalam kitab (bukan bahasa sehari-hari). Sastra dapat juga diartikan sebagai kitab suci (Hindu), ilmu pengetahuan, pustaka, primbon (berisi ramalan, hitungan dsb). Sedangkan kesusastraan berarti karya tulis, yang jika dibandingkan dengan tulisan lain memiliki berbagai ciri keunggulan seperti keaslian, keartistikan, keindahan dalam isi dan ungkapan.

Dalam bahasa Arab, sastra dikenal dengan istilah adab. Sedangkan kata adab itu sendiri memiliki banyak makna sesuai dengan masa di mana kata tersebut dipergunakan. Misalnya pada masa jahiliyah, orang Arab menggunakan kata adbun (bukan adab) yang berarti undangan untuk menyantap makanan. Berbeda dengan masa shadrul Islam, kata adab mencakup makna pendidikan lisan dan pendidikan budi pekerti, serta menjahui kebiasaan yang tercela. Dan pada masa Bani Umayyah kata adab hanya terfokus pada makna pengajaran (ta`lim).

Ada para pakar yang membuat definisi sastra berdasarkan sifat karya sastra yang imajinatif atau rekaan. Dengan demikian, rekaan menjadi criteria untuk menggolongkan mana karya sastra yang disebut sastra, dan mana yang bukan sastra. Di pihak lain ada yang mencoba merumuskan pengertian sastra dari sudut hakekatnya sebagai karya kreatif. Namun jangan dilupakan bahwa batasan kreatif dan tidak kreatif sama saja kaburnya dengan batasan antara sastra dan non-sastra.

Walaupun usaha mendefinisikan sastra sudah dilakukan oleh banyak ahli sastra, namun batasan yang tepat mengenai apa hakekat 
sastra itu belum dapat dirumuskan. Batasan-batasan yang ada seringkali hanya didasarkan pada aspek-aspek tertentu sehingga masih terdapat kemungkinan untuk disanggah atau dipertanyakan. Hal tersebut disebabkan karena adanya beberapa celah kelemahan atau terlalu longgarnya batasan-batasan yang ada. Jadi definisi-definisi sastra yang ada, pada umumnya masih bersifat parsial sehingga belum mampu memberikan gambaran yang utuh mengenai hakekat sastra. Menurut Jan Van Luxemburg, keparsialan definisi tersebut dapat digolongkan menjadi empat macam; 1) Sering dilupakan antara definisi deskriptif mengenai sastra dengan definisi evaluatif yang berkaitan dengan nilai, 2) Definisi yang ada bersifat ontologis, dan melupakan definisi dalam situasi para pembaca sastra, 3) Definisi yang ada terlalu menitikberatkan pada contoh sastra Barat, khususnya sejak zaman Renaisance tanpa memperhitungkan sastra di luar zaman tersebut, dan 4) Definisi yang ada hanya berkecendrungan dengan jenis-jenis sastra tertentu.

Merumuskan pengertian atau hakekat sastra secara utuh memang sangat sulit. Namun demikian, berdasarkan historis paling tidak secara umum dapat dirumuskan bahwa sastra adalah karya fiksi yang merupakan hasil kreasi berdasarkan luapan emosi yang spontan dan mampu mengungkapkan aspek estetik, baik yang didasarkan pada aspek kebahasaan maupun aspek makna. Patokan estetik inilah yang seringkali dijadikan dasar penilaian pada sebuah teks sastra. Bahkan beberapa ahli sastra beranggapan, bahwa suatu teks sastra dianggap berbobot atau tidak, itu ditentukan oleh nilai estetik yang dikandungnya (Fananie, 2001:3).

Estetika pertama kali digaungkan oleh Alexander Gottlieb Baumgarten, seorang filosof rasionalis Jerman didefinisikan sebagai "pengetahuan tentang keindahan pada alam dan seni". Dalam perkembangan berikutnya, pandangan mengenai estetika dari beberapa filosof berbeda-beda, karena mereka melihat estetika berdasarkan perspektif yang berbeda pula. Di satu pihak, mereka melihat estetika tidak lebih dari pada pengejawantahan Tuhan. Karena hanya Tuhan-lah yang merupakan sumber keindahan. Tuhan adalah Dzat Yang Maha Sempurna dan keindahan hanya ada dalam kesempurnaan. Homerus 
misalnya, ia menjalin kekuatan Ilahi untuk menghadirkan refleksi estetik. Itulah Muse, suatu cinta suci dan lembut mentransfigurasikan manusia dalam alam menjadi bercahaya (Fananie, 2001:3).

Juga seperti yang disampaikan Plato, bahwa keindahan mengacu kepada ide-ide dan gagasan-gagasan. Dunia ide adalah dunia Ilahi. Jadi, keindahan mengacu kepada dunia Tuhan. Hal ini disebabkan, sesuai dengan pandangan bahwa yang indah adalah yang benar, karena kebenaran yang sejati hanya ada pada dunia Tuhan. Kebenaran realitas selalu mengacu kepada dunia Tuhan tersebut. Sesuai dengan sifatnya yang mengacu maka kebenaran realitas tidak akan pernah menyamai kebenaran Tuhan. Karya seni adalah sesuatu yang selalu disepakati mengandung keindahan. Seni identik dengan indah. Keindahan tersebut tidak akan pernah sampai menyamai keindahan yang ada pada dunia Tuhan. Artinya, seniman hanya meniru keindahan abadi, master yang ada pada dunia Tuhan (Atmazaki, 1990:89).

Berbeda dengan Aristoteles, yang beranggapan bahwa keindahan suatu benda hakikatnya tercermin dari keteraturan, kerapihan, keterukuran, dan keagungan. Keindahan yang dicapai adalah keserasian bentuk (wujud) yang setinggi-tingginya. Bagi Aristoteles, karya seni dinilai memiliki nilai keindahan yang lebih dibandingkan keindahan yang terjadi di alam, meskipun tidak tertutup terdapatnya karya seni yang lebih rendah daripada alam. Konsep mimesis (peniruan alam) kemudian menjadi cirri utama estetika Yunani dalam percaturan filsafat. Pendapat ini merupakan bias dalam menafsirkan pendapat arsitoteles. Aristoteles justru menyatakan "tragedi" ketika manusia harus meniru alam, atau meniru bentuk makhluk-makhluk di alam. Beberapa karya seni memang menunjukkan "imitasi" alam yang membawa kebaikan, karena dibuat untuk memperbaiki sesuatu yang dinilai buruk. Melalui seni, manusia harus mampu membuat sesuatu menjadi lebih baik daripada yang sebenarnya. Menurut Aristoteles, cirri khas seni adalah kemampuannya membedah alam dan mengupas esensinya. Seni adalah karya cipta yang dibimbing oleh pikiran dalam arti yang sebenarnya, dan gagasan Aristoteles ini dinilai sebagai gagasan estetika yang bernilai inspiratif 
dan membumi dibandingkan estetika yang berorientasi pada kesadaran yang lebih tinggi (Sachari, 2002:5).

Seni juga berkaitan dengan masalah moral dan agama. Seperti yang diungkap Imam al-Ghazali, bahwa efek yang ditimbulkan rasa seni terhadap jiwa manusia sangat besar, dan karenanya menentukan moral dan penghayatan keagamaannya. Apabila masalah estetika hanya dikaitkan dengan selera dan kesenangan sensual, atau kesenangan inderawi, maka nilai seni itu merosot. Gagasan Baumgarten yang memandang estetika sebagai pengetahuan mengenai pengamatan indera bertentangan dengan tujuan ilmu yang sebenarnya. Bagi Gadamer tujuan pengetahuan yang sebenarnya ialah menyerap kebenaran universal dan mengatasi subjektivitas. Karena itu, pengetahuan, termasuk estetika tidak boleh ditentukan hanya oleh kesenangan dan hasil pengamatan indera (Hadi, 2004:34).

Pendapat lain mengatakan, keindahan itu tergantung kepada konvensi-konvensi suatu masyarakat. Baik dari segi penciptaan, maupun dari segi penikmatan, dan konvensi memainkan peranan utama dalam menentukan keindahan. Namun perlu diketahui, bahwa konvensi selalu berubah sesuai dengan perubahan zaman. Perubahan zaman membawa perubahan niali-nilai, termasuk nilai-nilai keindahan itu sendiri. Jelasnya, kesepakatan suatu masyarakat tentang keindahan hari ini menandakan adanya yang tidak indah lagi pada hari kemarin. Karena itu, mendasari keindahan kepada konvensi berarti menempatkan keindahan pada pertentangan antara yang lama dengan yang baru.

Secara hirarki keindahan itu terbagi menjadi 3 macam, yaitu: 1) keindahan dalam arti luas, 2) keindahan dalam arti estetik murni, dan 3) keindahan dalam arti sederhana. Keindahan dalam arti luas adalah keindahan yang identik dengan kebenaran, yang indah hanya yang mengandung kebenaran, dan yang mengandung kebenaran pasti mempunyai nilai keindahan. Keindahan dalam arti estetik murni yaitu menyangkut dengan pengalaman estetik seseorang, pengalaman yang menyebabkan seseorang merasa lebur sewaktu berhadapan dengan 
keindahan itu sehingga ia tidak menemukan lagi jarak antara dirinya dengan objek keindahan itu. Sedangkan keindahan dalam arti sederhana menyangkut penerapan panca indera secara lahir.

Mengutip Atmazaki (1990:90), hirarki demikian sebenarnya merupakan tahap yang dialami seseorang dalam persentuhannya dengan keindahan. Pertama, keindahan itu melekat melalui panca indera. Kemudian hal itu berkontemplasi karena keindahan itu mempengaruhi pengalaman dan kesadaran jiwanya. Akhirnya ia menemukan nilai dan kualitas kebenaran yang terkandung di dalamnya.

Dalam visi estetika Jan Mukarovsky nilai estetika adalah sesuatu yang lahir dari tegangan antara pembaca dan karya, bergantung pada aktivitas pembaca selaku pemberi arti. Karena itu, nilai estetik adalah proses yang terus-menerus, bukan perolehan yang tetap, sekali diperoleh tetap dimiliki. Visi inilah yang dapat menjelaskan mengapa sebuah karya seni terus-menerus dapat memikat penikmat, mengapa sebuah karya sastra yang baik dapat dinikmati kembali walaupun dibaca untuk kesepuluh kali (Teeuw, 2003:294).

Selain mengandung nilai estetika, karya sastra juga harus memiliki nilai moral dan nilai yang bersifat konsepsional. Ketiga nilai tersebut tidak dapat dipisahkan. Sesuatu yang estetis adalah sesuatu yang memiliki nilai-nilai moral, ia bukan hanya semacam sopan santun atau etika belaka. Ia adalah nilai yang berpangkal pada nilai-nilai tentang kemanusiaan. Demikian juga nilai yang bersifat konsepsional, dasarnya adalah juga nilai tentang keindahan yang sekaligus menerangkan nilai tentang moral (Esten, 1990:7).

Abdul Aziz memberikan satu batasan yang cukup komprehensip (jami'mani'), bahwa karya sastra ialah karya yang memiliki ciri kekhasan yang mutlak, yaitu keindahan dan keartistikan. Karya-karya yang tidak mengandung nilai-nilai keindahan dan keartistikan tidak dapat disebut sebagai karya sastra (Al-Faishal, 1405:8). Juga seperti yang dikatakan Panuti Sudjiman, sastra adalah karya lisan atau tulisan yang memiliki berbagai ciri keunggulan seperti keorsinilan, keartistikan, 
keindahan baik dalam isinya maupun ungkapannya (Sudjiman, 1990:71).

Sekalipun definisi sastra yang ada masih membuka peluang untuk diperdebatkan, namun kiranya perlu untuk menentukan ciricirinya karena ia lebih urgen dari pada membuat definisi yang holistik dan komprehensip. Ciri-ciri tersebut adalah sebagai berikut:

Pertama, sastra bukanlah suatu komunikasi yang praktis, yang isi dan maksudnya langsung terlihat, tertangkap, dan terpahami manakala membaca atau mendengar sebuah komunikasi seperti membaca bukubuku lainnya yang tidak bernama sastra. Dalam sastra makna tersirat lebih dominan dari pada makna tersurat. Efek pengasingan dalam sastra melambatkan pencerapan kita terhadap maknanya. Tetapi justru di sana pula letak intensitas maknanya.

Kedua, karya sastra adalah karya kreatif, bukan semata-mata imitatif. Kreatif dalam sastra berarti ciptaan, dari tidak ada menjadi ada. Baik bentuk maupun makna merupakan kreasi. Bahasa sebagai sistem primer menurut Jurij Lotman, seorang ahli semiotika berkebangsaan Rusia, telah mempunyai makna sebelum disusun menjadi sastra sebagai sistem sekunder. Kreatif dalam sastra juga berarti pembaharuan. Teeuw menegaskan bahwa pemerkosaan dan pelanggaran konvensi adalah sifat karya seni yang khas, malahan pada masa tertentu, hasil dan nilai sebuah karya seni sebagian besar ditentukan oleh berjaya tidaknya dalam usaha mendobrak dan merombak konvensi.

Ketiga, karya sastra adalah karya yang imajinatif. Ia bukan representasi dari kenyataan. Akan sia-sia bila mengharapkan dapat berjumpa dengan kehidupan sebagaimana disajikan dalam karya sastra. Oleh karena imajinatif maka dengan sendirinya ia juga bersifat subyektif, baik subyektif dalam penciptaan maupun subyektif dalam pemahaman. Keselarasan yang ada dalam karya sastra tidak secara otomatis berhubungan dengan keselarasan yang ada dalam masyarakat tempat sastra itu lahir.

Keempat, karya sastra adalah karya otonom. Karya sastra adalah karya yang hanya patuh pada dirinya sendiri. Tentang otonomi karya 
sastra, sebagaimana ungkap Teeuw, karya sastra atau karya seni pada umumnya merupakan keseluruhan yang bulat, yang berdiri sendiri, yang otonom dan yang boleh dan harus kita pahami dan tafsirkan pada sendirinya, sebuah dunia rekaan yang tugasnya hanya satu, patuh setia pada dirinya sendiri. Tetapi pada pihak lain tidak ada karya seni mana pun juga yang berfungsi dalam situasi kosong karena ia merupakan aktualisasi tertentu dari sistem dan kode budaya.

Kelima, karya sastra adalah karya yang kohern. Koherensi dalam karya sastra mengandung arti tidak satu unsur pun yang tidak fungsional, walaupun hanya sebuah tanda titik. Koherensi dalam karya sastra juga membedakannya dengan karya-karya non-sastra. Dalam karya sastra setiap unsur mempunyai hubungan dengan unsur lain. Begitu padunya hubungan itu, sehingga apabila ditukar letaknya, apalagi diganti unsurnya maka keseluruhan karya itu akan kehilangan kekuatannya sebagai karya sastra dan akan menimbulkan perubahan makna. Karena yang dipahami dalam karya sastra bukan "meaning" melainkan makna "significance".

Keenam, konvensi suatu masyarakat amat menentukan mana karya yang dapat disebut sebagai karya sastra, dan mana yang tidak. Karya sastra pada suatu masyarakat belum tentu disebut sastra oleh masyarakat yang lain karena perbedaan konvensi yang mereka anut. Karya sastra pada masa tertentu mungkin tidak dianggap karya sastra pada masa berikutnya karena perubahan konvensi yang diakibatkan perubahan tata nilai dalam kehidupan.

Ketujuh, sastra tidak sekedar bahasa yang ditulis atau diciptakan, ia tidak sekedar permainan bahasa. Akan tetapi ia adalah bahasa yang mengandung makna lebih. Ia menawarkan nilai-nilai yang dapat memperkaya rohani dan meningkatkan mutu kehidupan. Bahkan ia mampu memenuhi hasrat manusia untuk berkontemplasi (Atmazaki, 1990: 22-24).

\section{Mimesis, Realitas, atau Mitos?}


Kalau karya sastra disebut sebagai karya kreatif dari seorang pengarang, maka muncul satu pertanyaan, apakah karya tersebut lahir begitu saja, ibarat hujan turun dari langit, ataukah ada keterkaitan dengan kenyataan dan fenomena lain? Seorang filosof Yunani, Plato telah membicarakan hubungan antara karya sastra dengan kenyataan dalam bukunya "Republic". Buku itu tidak semata-mata berisi uraian mengenai teori-teori sastra, tetapi juga berisi tentang sikap dan pendiriannya mengenai sebuah negara ideal yang menjadi obsesi dalam hidupnya.

Negara ideal, dalam pandangan Plato, adalah negara yang mengacu kepada dunia ide, atau dunia gagasan. Karena ide dan gagasan tersebut identik dengan kebenaran. Setiap perbuatan manusia di negara ideal harus mengacu kepada kebenaran, sementara kebenaran tertinggi hanya ada pada dunia ide, dunia Ilahi (Rapar, 1996: 103). Karya seni menurut Plato tidak dapat sampai ke dunia ide, ia hanya tiruan. Sedangkan tiruan tidak pernah sama dengan yang ditiru.

Dalam teorinya, Plato menggunakan istilah mimesis, atau tiruan. Karya sastra meniru kenyataan, sementara kenyataan sehari-hari hanyalah tiruan dari dunia ide yang merupakan kenyataan tertinggi yang terletak pada dunia Ilahi. Para sastrawan hanya meniru kenyataan sehari-hari yang merupakan tiruan pula dari dunia ide, dunia Ilahi. Puisi yang diciptakan penyair hanyalah tiruan dari dunia nyata. Sebab itulah karya seni, puisi misalnya, lebih rendah mutunya dari pada kenyataan sehari-hari karena ia berada dua tingkat di bawah kenyataan tertinggi, yaitu dunia Ilahi.

Dari uraian di atas, Plato membagi kenyataan menjadi tiga tingkatan. Pertama, kenyataan yang tertinggi, yaitu kenyataan yang berada pada dunia ide, atau dunia Ilahi yang langsung berhubungan dengan kebenaran hakiki. Yang benar dan yang baik hanya ada pada dunia Ilahi. Kedua, kenyataan yang berada di bawah kenyataan ideal, yaitu kenyataan sehari-hari. Kenyataan ini hanya meneladani kenyataan hakiki. Sesuai dengan sifatnya, yaitu meneladani, maka kenyataan kedua ini tidak dapat sepenuhnya dipercaya. Dan ketiga, kenyataan 
imajinatif yang menjelma dalam bentuk karya seni. Karya seni tidak langsung berhubungan dengan kenyataan hakiki, tetapi meneladani kenyataan sehari-hari, atau kenyataan kedua (Atmazaki, 1990: 40).

Walaupun Plato menempatkan karya seni pada tataran ketiga, bukan berarti karya tersebut tidak bernilai sama sekali. Plato tetap memberi tempat dalam negara ideal untuk karya seni dan untuk seniman, asal dipenuhi beberapa syarat. Di antaranya, seni yang bermanfaat adalah seni yang berlandaskan moral yang baik, maka seorang seniman harus bermoral. Seni harus benar (setepat mungkin) menggambarkan sesuatu, dan tema seni harus mengekspresikan hal-hal yang baik.

Pandangan Plato di atas mendapat tantangan keras dari muridnya, adalah Aristoteles. Bagi dia karya seni tidak semata-mata tiruan dari kenyataan sehari-hari. Seniman tidak menyampaikan kenyataan sehari-hari sebagaimana adanya. Akan tetapi karya seni adalah kenyataan artistik, yang diciptakan dalam suatu proses kreatif. Tidak disangkal bahwa kenyataan dalam karya seni bersumber dari kenyataan sehari-hari, tetapi kenyataan dalam karya seni telah menampilkan kenyataan baru berdasarkan kesanggupan seniman mengolah dan memadukan imajinasi dan kenyataan.

Kebenaran dalam karya seni tidak perlu diukur dengan kebenaran yang ada dalam kenyataan sehari-hari. Karena kebenaran yang ada dalam karya seni adalah kebenaran dalam rangka keseluruhan karya yang imajinatif.

Imajinasi merupakan wilayah khusus, daerah otonom, yang tidak perlu dicocok-cocokkan dengan kenyataan. Walaupun sesuatu bersifat imajinatif tetapi ia tidak harus irrasional. Sesuatu yang bersifat imajinatif boleh jadi terjadi dalam kehidupan nyata, karena bagaimanapun juga karya sastra merupakan refleksi kehidupan manusia. Sebagai sebuah kreasi imajinasi, karya sastra memang tidak mampu menegakkan diri menjadi salah satu pusat legitimasi persoalanpersoalan sosial atau proses-proses institusional masyarakat yang memilikinya. Ia menjadi dusta jika kita memaksakan kategori-kategori 
logis yang umum padanya. Bahkan ia menjadi nonsens andaikata kita meminta penjelasan rasional-ilmiah kepadanya tentang berbagai persoalan keseharian (Dahana, 2001: 25).

Mimesis dalam pandangan Aristoteles lebih luas dari pada Plato. Bagi Aristoteles yang penting dalam karya seni adalah sejauh mana ia mampu memperlihatkan kenyataan baru yang dapat memperluas cakrawala manusia tentang kenyataan yang dihadapinya sehari-hari. Aristoteles justru meletakkan karya seni di atas kenyataan fenomenal. Kerja seorang penyair lebih berharga dari pada kerja seorang tukang. Karya seni membuat manusia menyadari keberadaannya sebagai manusia yang mempunyai akal, pikiran, dan perasaan.

Karena itu, seperti yang diungkap Ekarini, pemikiran Aristoteles tentang karya sastra mencakup beberapa konsep; pertama, seni sebagai penyucian jiwa lewat satu proses yang disebut katharsis (penyucian). Kedua, seniman menciptakan dunianya sendiri. Penyair tidak meniru kenyataan, melainkan mencipta dunianya sendiri dengan probability. Ketiga, seniman lebih tinggi dari pada tukang. Dan keempat, karya seni merupakan sarana pengetahuan (Ekarini, 2003: 23).

Kemampuan berimajinasi merupakan kemampuan kreatif pengarang. Kreatifitas pengarang memungkinkan munculnya unsur fiksionalitas dalam karya sastra. Seseorang pengarang tidak mungkin berimajinasi kalau tidak ada yang melandasinya, yaitu kenyataan fenomenal. Tidak akan ada imajinasi tanpa kenyataan, dan tidak akan ada peneladanan tanpa imajinasi. Kehidupan manusia senantiasa berada antara kenyataan dan impian (Atmazaki, 1990:41).

Antara mimesis dan kreativitas yang melahirkan unsur fiksionalitas dalam karya sastra tidak dapat dipisahkan. Karya sastra adalah dunia fiksi yang bertolak dari kenyataan. Tidak ada karya sastra yang sepenuhnya meneladani kenyataan, di samping juga tidak ada yang sepenuhnya fiksi. Apabila karya sastra sepenuhnya kenyataan maka ia akan berubah menjadi karya sejarah, dan apabila sepenuhnya fiksi maka tidak akan ada seorang pun yang mampu memahaminya. Karena itu, keterpaduan antara mimesis dan kreativitas pengarang 
dalam menciptakan karya sastra menentukan keberhasilan sebuah karya sastra.

Dari sisi bahasa, kaitan antara mimesis dan kreativitas juga memperlihatkan hubungan dialektika. Bahasa yang terdiri atas urutan kata, yang digunakan sehari-hari tidak merupakan pelahiran kenyataan semata tanpa diwarnai oleh unsur fiksi, imajinasi, atau fantasi. Makna yang dikandungnya tidak secara langsung merujuk kepada kenyataan, walaupun juga tidak dapat terlepas dari unsur kenyataan. Bahasa, termasuk sastra bukanlah representasi dari kenyataan, tetapi juga tidak fantasi belaka, melainkan alat yang secara konseptual didasarkan atas pengetahuan dan pengalaman.

Kenyataan bagi manusia tidaklah murni, tetapi dipengaruhi oleh wawasannya yang telah terkonstruksi oleh alam. Kenyataan bagi manusia selalu diarahkan oleh norma-norma, sistem, ideologi, pengetahuan, pengalaman, konvensi, dan aturan yang berbeda-beda pada setiap masyarakat, dan yang mungkin akan berubah sepanjang zaman. Jadi, manusia tidak menerima kenyataan sebagai kenyataan, tetapi kenyataan sebagai ditafsirkan.

Sejak zaman klasik karya sastra hanya meniru dan meneladani ciptaan Tuhan, sehingga ia berada di bawah ciptaan-Nya, maka bermulalah keagungan pengarang ditonjolkan. Secara berangsur-angsur pengarang dianggapnya sebagai manusia genius, sebagai manusia super, dan semakin mendapat tempat. Aristoteles mengatakan, pengarang tidak sekedar meniru sebagaimana dikatakan Plato. Tetapi ciptaan Tuhan hanya sekedar tempat bertolak. Pengarang justru menciptakan kenyataan baru berdasarkan kenyataan objektif. Daya khayal dan kreativitas pengarang telah mampu menciptakan kenyataan yang lebih kurang terlepas dari kenyataan alami. Akhirnya sampai ke tahap yang paling "lancang", yaitu dengan menyebutkan bahwa pengarang sebagai pencipta telah menyamai Tuhan. Tuhan tidak lagi dianggap sebagai Yang Maha Pencipta. Pengarang dianggap sebagai pencipta yang menciptakan karya dari kekosongan, tanpa meniru ciptaan Tuhan, tanpa ada yang diteladani. 
Dalam tradisi masyarakat jahili, mereka menganggap para penyair itu memiliki pengetahuan magis, bahkan menurut Ahmad Amin, mereka disebut sebagai ahlul ma`rifah (Ahmad Amin, 1975: 55), karena mereka mampu memprediksi apa yang akan terjadi. Dengan demikian, karya sastra bagi masyarakat jahili bukan untaian kata-kata yang disuarakan lisan tanpa makna (absurd) melainkan sebagai sarana (sakral) yang ampuh untuk membakar semangat, meredam emosi, dan membawa harum nama kabilah. Barangkali kelancangan inilah yang menyebabkan Tuhan menyatakan dalam al-Qur'an, surat Al-Syu'ara' ayat 224 bahwa penyair adalah orang yang sesat, karena tidak ada yang lebih lancang dari mengatakan lebih dari Tuhan. Keegoan seperti ini telah merajalela selama berabad-abad di Eropa yang mencapai puncaknya pada zaman Romantik, akhir abad ke-18. Pada zaman ini, individualitas, orisinalitas, dan kreativitas mendapat tempat yang paling tinggi.

Mimesis adalah hak preogatif Tuhan, hanya Tuhan yang boleh membuat tiruan, atau mitasi. Manusia adalah contoh paling konkrit dari tiruan ini, sebab seperti tertulis dalam Genesis, Tuhan menciptakan manusia sesuai dengan citra-Nya. Mengutip Manneke, dalam pengertian mimesis yang dikedepankan Plato, Tuhan merupakan realitas tertinggi dan bersifat abstrak, sementara realitas material yang inderawi adalah realitas sekunder yang sesungguhnya merupakan imitasi dari yang ideal. Seni, termasuk tulisan dipandang rendah nilainya karena merupakan tiruan dari tiruan. Sedangkan di dalam Perjanjian Lama, tulisan pertama-tama bukanlah suatu tiruan, melainkan merupakan sebuah tanda yang bersifat metonimis. Manusia melalui upayanya sendiri tidak mampu menghadirkan Tuhan dalam tulisan, kecuali atas kehendak dan perintah Tuhan sendiri. Oleh sebab itu, ada larangan untuk mensakralkan atau menyembah segala sesuatu yang diciptakan manusia atau mengasumsikan kehadiran Tuhan dalam karya-karya cipta itu. Bahkan secara lebih tegas lagi, Tuhan melarang manusia untuk melakukan peniruan dalam bentuk apa pun terhadap apa pun yang ada di alam ini, kecuali, sekali lagi, atas perintah-Nya (Junus, 1981:106). 
Sementara Umar Junus berpendapat lain, setiap karya satra adalah mitos (norma, ideologi, konvensi, dan lain lain), mungkin mitos pengukuhan, mungkin pula mitos pembebasan, atau kontra mitos. Apabila karya sastra membenarkan mitos yang ada dalam karya sebelumnya, atau mitos yang hidup dalam masyarakat maka karya sastra itu disebut membawa mitos pengukuhan. Sebaliknya, apabila karya sastra menentang mitos yang sudah ada maka karya sastra tersebut membawa mitos pembebasan, dan dengan sendirinya ia membawa, atau membuat mitos baru sehingga terjadi kontra mitos (Junus, 1981:74).

Karya sastra sesungguhnya berakar dari masa prasejarah dalam wujud sastra lisan dan bentuk-bentuk mitos. Sebagaimana diungkap Richard Chase, mitos adalah karya sastra yang harus dipahami sebagai kreasi estetik dari imajinsai manusia. Pengertian mitos sebagai seni sastra berkaitan dengan fungsi primer mitos dalam pemikiran manusia sebelum munculnya bidang-bidang lain, seperti religi, ekonomi, teologi, dan lainnya. Sebagai ekspresi kesenian, mitos mengungkapkan kekuatan magis impersonal yang mengacu kepada pengalaman akan hal-hal yang luar biasa indah, menakutkan, dan bahkan mengagumkan (Chase, 1969:70).

Dalam pandangan Vickery, mitos membentuk acuan, dan dari acuan itu muncul sastra yang bersifat psikologis, histories, simbolis, ekspresif, dan impresif. Elemen-elemen kesusasteraan, seperti alur, tema, perwtakan, dan citraan pada umumnya ditemukan di dalam mitos dan cerita-cerita rakyat. Mitos merangsang penciptaan seni, dan lebih dari itu, ia menawarkan konsep dan pola-pola kritik yang dapat dimanfaatkan untuk menginterpretasi karya sastra. Dengan demikian, pengetahuan mengenai tata bahasa mitos akan dapat memberikan pemahaman yang lebih utuh dalam membaca dan memahami karya sastra (Vickery, 1982:83).

Memang sulit menentukan, apakah karya sastra sebuah mitos atau kenyataan. Pada kenyataannya di tengah masyarakat, jika peristiwa yang ada dalam karya sastra sesuai dengan sistim ideologi 
yang mereka anut maka mereka akan menyukainya. Dan sebaliknya, jika peristiwa itu tidak sesuai maka mereka tidak menyukainya. Sebenarnya, bila dipikir secara rasional, tidak perlu membenci atau tidak membenci sebuah karya sastra, kalau karya itu dianggap sebuah khayal. Namun begitulah kenyataan masyarakat penikmat karya sastra.

Dan tidak bisa dielak, sesungguhnya kehidupan manusia, dan dengan sendirinya hubungan antar manusia dikuasai oleh mitos-mitos. Sikap kita terhadap sesuatu ditentukan oleh mitos yang ada dalam diri kita. Mitos ini menyebabkan kita menyukainya, atau membencinya. Dengan demikian, mitos akan meyebabkan kita mempunyai prasangka tertentu terhadap sesuatu hal yang dinyatakan dalam mitos. Hanya lewat persentuhan diri kita dengan hal tertentu tadi kita dapat mengetahui kebenaran, ataukah kesalahan dari mitos tadi. Persentuhan ini mungkin dapat memperkuat mitos itu, atau mungkin pula dapat meniadakannya.

Memang tidak mungkin ada kehidupan tanpa mitos. Kita hidup dengan mitos-mitos yang membatasi segala tindak-tanduk kita. Ketakutan atau keberanian kita terhadap sesuatu ditentukan oleh mitosmitos yang kita hidup bersamanya. Manusia tidak dapat memisahkan antara mitos dan kenyataan. Mereka hidup di antara keduanya. Di dalam kenyataan sehari-hari manusia menemukan mitos, dan sebaliknya, di dalam mitos mereka menemukan kenyataan. Demikian pula keberadaan karya sastra, ia adalah sebuah mitos sekaligus adalah kenyataan.

\section{Penutup}

Karya sastra adalah karya lisan atau tulisan yang memiliki ciri kekhasan yang mutlak, yaitu keorsinilan, keartistikan, keindahan, baik dalam isinya maupun ungkapannya. Ia merupakan karya kreatif, bukan semata-mata imitatif. Kreatif dalam sastra berarti ciptaan, dari tidak ada menjadi ada, baik bentuk maupun makna.

Karya sastra adalah dunia fiksi yang bertolak dari kenyataan. Tidak ada karya sastra yang sepenuhnya meneladani kenyataan, di 
samping juga tidak ada yang sepenuhnya fiksi. Apabila karya sastra sepenuhnya kenyataan maka ia akan berubah menjadi karya sejarah, dan apabila sepenuhnya fiksi maka tidak akan ada seorang pun yang mampu memahaminya. Karena itu, keterpaduan antara mimesis dan kreativitas pengarang untuk membentuk kenyataan baru (karya sastra) sangat menentukan nilai sebuah karya sastra. $\square$

\section{DAFTAR PUSTAKA}

Al-Faishal, Abd al-Aziz bin Muhammad. 1405 H. Al-Adab al- 'Arabi Wa Tarikhuhu. Riyadh: al-Mamlakah al-'Arabiyah al-Su'udiyah.

Al-Khafaji, M. Mun 'im. 1996. Al-Syi`r al-Jahili. Libanon: Dar al-Kuttab. Amin, Ahmad. 1975. Fajr al-Islam. Tanpa Tempat: Tanpa Penerbit. Atmazaki. 1990. Ilmu Sastra: Teori dan Terapan. Padang: Angkasa Raya. Budiman, Manneke. 1995. "Tuhan dalam Mimesis: Representasi Tuhan dalam Paradiso dan Bhagavadgita", dalam Jurnal Ulumul Qur’an, Nomor 2, Volume VI. 
Chase, Richard. 1969. "Notes on the Study Myth", dalam John. B. Vickery, Myth and Literature. Lincoln: University of Nebraska Press.

Dahana, Rahdar Panca. 2001. Kebenaran dan Dusta dalam Sastra. Magelang: Indonesiatera.

Esten, Mursal. 1990. Kesusastraan Pengantar Teori dan Sejarah. Bandung: Angkasa.

Fananie, Zainuddin. 2001. Telaah Sastra. Surakarta: UMS Press.

Faruk. 1999. Pengantar Sosiologi Sastra: dari Strukturalisme Genetik sampai Post-Modernisme. Yogyakarta: Pustaka Pelajar.

Hadi W.M, Abdul. 2004. Hermeneutika, Estetika dan Religiusitas. Yogyakarta: Mahatari.

Iswanto. 2001. Penelitian Sastra dalam Perspektif Struktur Genetik, dalam Jabrohim, "Metodologi Penelitian Sastra". Yogyakarta: Hanindita Graha Widia.

Junus, Umar. 1981. Mitos dan Komunikasi. Jakarta: Sinar Harapan.

Rapar, Jan Hendrik. 1996. Pengantar Filsafat. Yogyakarta: Kanisius.

Sachari, Agus. 2002. Estetika: Makna, Simbol dan Daya. Bandung: ITB.

Saraswati, Ekarini. 2003. Sosiologi Sastra: Sebuah Pemahaman Awal. Malang: UMM Press.

Sudjiman, Panuti. 1990. Kamus Istilah Sastra. Jakarta: Universitas Indonesia Press.

Tedjoworo, H. 2001. Imaji dan Imajinasi: Suatu Telaah Filsafat Postmodern. Yogyakarta: Kanisius.

Teeuw, A. 2003. Sastera dan Ilmu Sastera. Jakarta: Pustaka Jaya.

Vickery, John. B. 1982. "Literature and Myth", dalam Jean Pierre Barricelli dan Joseph Gibaldi (Ed), Interrelations of Literature. (New York: The Modern Language Association of America. 